\title{
Genetic improvement of Pseudomonas aeruginosa and Bacillus cereus for controlling root knot nematode and two weeds under laboratory conditions.
}

\author{
Shereen AH. Mohamed ${ }^{1, *}$, Hoda H. Ameen ${ }^{2}$, Usama S. Elkelany ${ }^{2}$, Mona A. El- \\ Wakeel $^{3}$, Mostafa MA. Hammam ${ }^{2}$ and Gaziea M. Soliman ${ }^{2}$ \\ ${ }^{1}$ Microbial Genetics Department, National Research Centre,${ }^{2}$ Plant Pathology Department National Research Centre ${ }^{3}$ Botany \\ Department, National Research Centre, Bohouth St, Dokki, P.O.Box12622, Giza, Egypt
}

Received: August 10, 2020; Revised: November 28, 2020; Accepted: January 2, 2021

\begin{abstract}
Plant parasitic nematodes and weeds are among the many biotic stresses that crops production suffers from during their growing season. Their management relies mainly on chemical pesticides. To decrease the extent of environment degradation and hazards to_human health and livestock due to the prolonged use of these chemicals, biological control using soil microorganisms is considered as a new ecofriendly and efficient control method. The main objective of this work was to improve the inhibition of two local bacterial strains, Pseudomonas aeruginosa and Bacillus cereus, against root knot nematode and weed seeds germination. To achieve this goal, protoplast fusion experiments were performed to gather all their properties in bacterial fusants and increase production of such toxic compounds. The results showed that $P$. aeruginosa was Rifampicin (Rif) resistance, but $B$. cereus was sensitive. In contrast to this $B$. cereus was Neomycin (Nm) resistance but $P$. aeruginosa was sensitive. A total of 40 fusants derived from the protoplast fusion experiments were selected by antibiotic resistance markers. SDS-PAGE analysis of the proteins confirmed that six recombinants acquired and expressed many specific protein bands from their parental strains. Three fusants, No. F7, F20 and F35, were selected and evaluated for their nematicidal potential in comparison with their parent against root knot nematode Meloidogyne incognita $\mathrm{J}_{2}$ and Echinochloa crus-galli and Portulaca oleracea seeds germination during in vitro experiments. Data showed that the fusants exhibited more antagonistic effects than their parents. After 72hrs of exposure, the three fusants caused-80.6, 96.5 and $97.7 \%$ mortality as compared to control, while the \% mortality after the same duration by $P$. aeruginosa, B. cereus singly and combined resulted in 52.2, 65.9 and 48.8\%, respectively as compared to control. Furthermore, the three fusants completely inhibited the germination of $P$. oleracea seeds and resulted in small radicals in E. crus-galli seeds as compared to control. These fusants show great potential to be selected as possible potential biopesticide.
\end{abstract}

Keywords: Protoplast fusion, SDS-PAGE, Pseudomonas aeruginosa, Bacillus cereus, Biocontrol, Meloidogyne incognita, Echinochloa crus-galli, Portulaca oleracea.

\section{Introduction}

Plant parasitic nematodes are one of the most damaging and widespread pathogens that cause global losses to crop production with an estimated loss of \$ 157 billion per year (Singh et al., 2015). Root-knot nematodes, Meloidogyne spp. especially $M$. incognita, has been found as the major limiting factor in vegetables production in tropical and subtropical regions. When the infective stage (J2) penetrates the roots and migrates directly to the vascular cylinder, it causes severe root galling, reduces nutrient and water utilisation efficiency, and affects photosynthetic products (Almaghrabi et al., 2013).

Throughout the world, weeds significantly contribute to reduce crop production, even more than all other pests combined (Adeux et al., 2019). They affect crop yield and quality by competing on space, nutrients, water, light and interfere with the distribution of fertilizers. Weed infestation resulted in yield losses of up to $45 \%$ in wheat (Hussain et al., 2017). Moreover, weeds act as reservoir for plant pathogens like nematodes, thus facilitating the reinfesting of crops in the next seasons (Byron et al., 2019).

Chemical pesticides have been used against plant parasitic nematodes and weeds with encouraging results since long, but many of these chemicals are proven to be carcinogens, infiltrate into ground water, build up residues in food plants and hazardous to the beneficial soil fauna and flora (Jabran et al., 2015). For more sustainable crop production, scientists are endorsing alternatives pesticides reduced toxicities. Using of non-pathogenic microbes with potential control activity against nematodes and herbicide resistant weeds has emerged as promising solution (Sayed et al., 2014). One of the most promising microorganisms without negative effects on the users, consumers or the environment are Plant-Growth Promoting Rhizobacteria (PGPR) ( Lee and Kim 2016). They affect nematodes and

\footnotetext{
*Corresponding author e-mail: shereen_asba@yahoo.com.
} 
weeds directly through the production of toxic compounds, siderophores, hydrogen cyanide, antibiotic, competition for space and indirectly through promoting plant growth and induction of systemic resistance (Lakshmi et al., 2015; Siddiqui et al., 2003).

Researchers have reported that mixtures of PGPR strains give better protection than one strain. But in certain cases, the establishment of more than one microorganism has no synergistic effect due to their different nutritional and environmental requirements. Furthermore, the combinations considered to exhibit improved efficacy under one set of conditions or one host may not produce equally favorable results under other set of conditions (Schisler et al., 1997). These open the door for utilizing some biotechnological approaches like protoplast fusion to gathering more than one mechanism of controlling in one individual and increasing the production of such toxic substances or enzymes (Abdel Salam et al., 2018; Soliman et al., 2018; Soliman et al., 2020).

The objectives of this study are to improve the antagonistic potential of such isolated bacteria using the protoplast fusion technique and to analyze the fusants products through SDS -PAGE technique. Under in vitro conditions, the antagonistic potential of fusants against root knot nematodes $M$. incognita $\mathrm{J} 2$ and $E$. crus-galli and $P$. oleracea weed seeds was evaluated in comparison to the parental types.

\section{Materials and Methods}

\subsection{Bacterial strains and growth conditions}

Two bacterial strains isolated from the Egyptian soil had nematicidal activity against plant parasitic nematodes. The bacterial isolates were identified based on 16S rDNA sequence analysis in the GenBank database nucleotides, as Bacillus cereus GEs (Accession No. LC215052) and Pseudomonas aeruginosa (under accession number LC215048) (Soliman et al., 2019). The aforementioned bacterial isolates were used as parent strains in the protoplast fusion experiment and bioassay tests. Bacterial strains were grown in Luria-Bertani (LB) medium (Davis et al., 1980) at $30^{\circ} \mathrm{C}$ for $24 \mathrm{~h}$ with shaking at $120 \mathrm{r} / \mathrm{min}$.

\subsection{Nematode inoculum preparation}

Cultrue of root-knot nematode $M$. incognita was established from single egg-mass of an adult female, previously identified by the morphological characteristics of the female perineal patterns (Taylor and Sasser, 1978) and reared on tomato plants (Lycopersicon esculentum Mill) cv. Alisa in the greenhouse of the Plant Pathology Department, National Research Centre. Nematode eggs were extracted from the infected tomato roots using $\mathrm{NaOCl}$ solution as described by (Hussey and Barker, 1973). To perform in vitro tested, eggs were allowed to hatch for $48 \mathrm{~h}$ at $30 \pm 2^{\circ} \mathrm{C}$ in an incubator to obtain the $2^{\text {nd }}$ stage larvae $\left(\mathrm{J}_{2}\right)$ to perform the in vitro test.

\subsection{Antimicrobial susceptibility}

Eleven antibiotics were used with final concentrations as follows: rifampicin (Rif), $100 \mu \mathrm{g} / \mathrm{mL}$; ampicillin (Amp), $100 \mu \mathrm{g} / \mathrm{mL}$; amikacin (Amk), $30 \mu \mathrm{g} / \mathrm{mL}$; streptomycin (Sm), $200 \mu \mathrm{g} / \mathrm{mL}$; kanamycin $(\mathrm{Km}), \quad 40 \mu \mathrm{g} / \mathrm{mL}$; tetracycline (Tc), $15 \mu \mathrm{g} / \mathrm{mL}$; chloramphenicol $(\mathrm{Cm}), 35$ $\mu \mathrm{g} / \mathrm{mL}$; gentamicin $(\mathrm{Gm}), 15 \mu \mathrm{g} / \mathrm{mL}$; polymyxin (Pmx), 50 $\mu \mathrm{g} / \mathrm{mL}$; neomycin $(\mathrm{Nm}), 40 \mu \mathrm{g} / \mathrm{mL}$; and erythromycin (Erm), $20 \mu \mathrm{g} / \mathrm{mL}$. The Kirby-Bauer disc diffusion method for antimicrobial susceptibility test was followed (NCCLS, 1999).

\subsection{Growth conditions and protoplast formation}

Cultivation of Bacillus cereus and Pseudomonas aeruginosa was carried out in $250 \mathrm{ml}$ flasks containing 70 $\mathrm{ml}$ of LB medium. Flasks were incubated for $24 \mathrm{hr}$. at $30^{\circ} \mathrm{C}$ with shaking at $120 \mathrm{rpm}$. Cells were harvested at the mid-point of the log phase by centrifugation at $5000 \mathrm{rpm}$ for $10 \mathrm{~min}$ and washed once with $1 \%$ N-laurylsarcosine. This was followed by washing three times with osmotic stabilizer buffer. The bacterial cells were then pelleted by centrifugation. Lysozyme was dissolved in osmotic stabilizer buffer to a final concentration of $15 \mathrm{mg} / \mathrm{ml}$, sterilized by $0.2 \mu \mathrm{m}$ millipore filter. Lysozyme was then, added to the cell pellets at final concentration of $1 / 10^{\text {th }}$ the volume and mixed thoroughly to make the suspension. The resulting mixture was incubated at $37^{\circ} \mathrm{C}$ for $4 \mathrm{~h}$. The viable protoplast were counted by spreading appropriate dilution onto LB medium solidified by adding $2 \%$ agar, where all inviable protoplasts were lysed and only the intact protoplast will grow after incubation according to (Soliman et al., 2020; Mohamed et al., 2016).

\subsubsection{The microscopic examination of the protoplasts}

Aliquots (1.0 ml each) of the parental protoplasts were mixed in 25\% PloyEthylene Glycol (PEG) 6000 and 100 $\mathrm{mM} \mathrm{CaCl}_{2}$ and incubated for $2 \mathrm{~h}$ at $30^{\circ} \mathrm{C}$. Aliquots of 100 $\mu \mathrm{l}$ from the mixture were prepared at 10 min intervals and diluted 10 times in protoplasting buffer. A total of six fusants were obtained after $2 \mathrm{~h}$ of fusion time on selective medium containing antibiotics Neomycin (Nm) and Rifampicin (Rif).

\subsubsection{Regeneration of protoplast}

The protoplasts in the reaction mixture were collected by centrifugation at $3000 \mathrm{rpm}$ for $10 \mathrm{~min}$. The precipitate was washed with Tris-HCl buffer with an osmotic stabilizer and the resulting precipitate was re-suspended in the same buffer. Protoplast suspension was diluted and overlaid on the LB medium solidified by adding $2 \%$ agar. (Mohamed et al., 2016).

\subsection{SDS-PAGE protein analysis}

The parental and fusant strains were grown in suspensions following the method of (El-Kawokgy et al., 2015). SDS-PAGE $12.5 \%$, was done according to the method of (Laemmli, 1970) to compare the products secreted by the parental strains and those secreted by fusant strains. After size fractionation, the proteins were visualized by staining with Coomassie Blue R-250 dye. The gels were scanned using Gel Doc 2000 system, and molecular masses were determined using Total Lab version 1.10 software based on protein marker purchased from Biomatik Corporation (Wilmington, Delaware, USA).

\subsection{Bioassay Tests}

2.6.1. Efficiency of the nematicidal effect of three fusants in comparison with their parents $P$. aeruginosa and $B$. cereus against $M$. incognita $J_{2}$

To evaluate the nematicidal activity, Petri dishes $6 \mathrm{~cm}$ in diameter were supplied separately with $4 \mathrm{ml}$ cell 
suspension of $P$. aeruginosa and $B$. cereus singly and combined and three fusants (No. F7, F20 and F35), then added one $\mathrm{ml}$ water containing $100 \pm 5$ freshly hatched $M$. incognita juveniles. Three concentrations were used and standard (S), S/2 and S/4 concentrations were prepared using distilled water. Each $\mathrm{ml}$ from standard containing $\left(2 \times 10^{6} \mathrm{cfu} / \mathrm{ml}\right)$ Five $\mathrm{ml}$ distilled water containing $100 \pm 5$ freshly hatched $M$. incognita juveniles served as control. All preparations and the control were replicated in five times. All dishes were kept in incubator at $35^{\circ} \mathrm{C}$ and loosely covered to permit aeration and lessen evaporation. Number of survived and dead individuals was counted for three days. After the exposure periods, the nematodes in each treatment were transferred to distilled water and left for $24 \mathrm{hrs}$ to see whether immobile nematodes resumed activity or not. The $\mathrm{J}_{2}$ mortality (\%) were assessed as compared to the control according to Mortality\%= [C1$\mathrm{C} 2 / \mathrm{C} 1] \mathrm{x} 100$, where $\mathrm{C} 1$ is the number of live nematodes larvae in control treatment and C2 is the number of live nematodes larvae in other treatments.

2.6.2. Examine the inhibitory effects of P. aeruginosa and $B$. cereus as parental strains and their fusants on germination and growth of $P$. oleracea and E. crus-galli weed seeds during in vitro analysis

Seeds of targeted weeds were surface sterilized by immersing in 95\% ethanol for a few seconds (3-4 s). After surface sterilization with $5 \%$ ethanol, seeds of targeted weeds were washed with sterilized distilled water several times to remove sterility. Filter paper was soaked with 3 $\mathrm{ml}$ of bacterial suspension (containing approximately $\left(2 \times 10^{6} \mathrm{cfu} / \mathrm{ml}\right)$ from $P$. aeruginosa and $B$. cereus as parental strains and the fusants No. F7, F20 and F35, were placed separately on Petri dish. Ten sterilized seeds from each weed species were placed separately in Petri dishes then incubated at $25^{\circ} \mathrm{C}$. For control, ten seeds from the two weed species were placed separately on filter paper soaked with $3 \mathrm{ml}$ of sterile water. Each treatment was replicated three times. Ten days later, germination of shoots and root lengths were observed.

\section{Results}

\subsection{Bacterial strains and antibiotic susceptibility}

Isolation of antibiotic genetic markers from $P$. aeruginosa and $B$. cereus was necessary for their manipulation. Data in Table 1 showed that $P$. aeruginosa was Rifampicin resistant and Neomycin sensitive in the contrary, B. cereus was Neomycin resistant and Rifampicin sensitive. Thus, Rifampicin and Neomycin were used as genetic markers for fusion products from the two strains.
Table 1. Antibiotics susceptibility of $P$. aeruginosa and B. cereus.

\begin{tabular}{lll}
\hline Bacterial strains & \multicolumn{2}{l}{ Antibiotic resistance } \\
\cline { 2 - 3 } & $\mathrm{Nm}$ & Rif \\
\hline$P a\left(\mathrm{Rif}^{\mathrm{r}}\right)$ & --- & +++ \\
$\mathrm{BC}\left(\mathrm{Nm}^{\mathrm{r}}\right)$ & +++ & -- \\
\hline $\mathrm{Pa}=\mathrm{P}$. aeruginosa, $\mathrm{Bc}=\mathrm{B}$. cereus & $+++:=$ Very good growth \\
$---=$ no growth & Rif $=$ Rifampicin & $\mathrm{Nm}=$ Neomycin
\end{tabular}

\subsection{The microscopic examination of the protoplasts}

The protoplast formation between the two selected strains, $P$. aeruginosa and $B$. cereus were tested periodically by microscopic examination. A total of six fusants were obtained after $2 \mathrm{~h}$ of fusion time on selective medium containing the two antibiotics $\mathrm{Nm}$ and Rif as shown in (Figure 1).

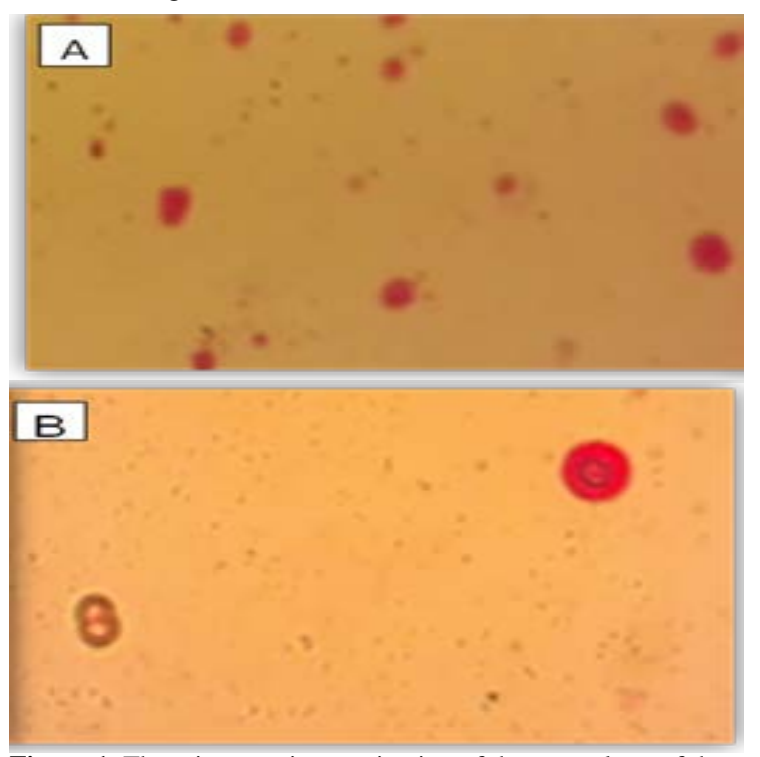

Figure 1. The microscopic examination of the protoplasts of the two parental strains $P$. aeruginosa and B. cereus (A) Protoplast formation .(B) Protoplast fusion

\subsection{Fusants isolation}

Neomycin (Nm) and Rifampicin (Rif) were added in LB medium as selective genetic marker, and only the fusants having combined the two selected isolates will grow in this media. Forty single colonies were randomly selected and retested for their ability to grow on the selective media. The fusants' growth was detected as follow: Six fusion products exhibited strong growth (F4, F5, F7, F15, F20 and F35), while forty fusion products showed weak growth and no growth in twenty single colonies refer to no fusion products.

\subsection{Expression of the parental strains protein bands in their fusants}

The SDS-PAGE protein patterns of the two parental strains $B$. cereus and $P$. aeruginosa and fusants are presented in (Figure 2). SDS-PAGE analysis of the total proteins of the two parental strains revealed a total of 11 and 12 protein bands, respectively. The molecular weights of parental strains ranged from 7 to $179 \mathrm{kDa}$. While the fusants showed a variable number of protein bands ranging from 11 in four fusants to 7 in one fusant (Table 2). 


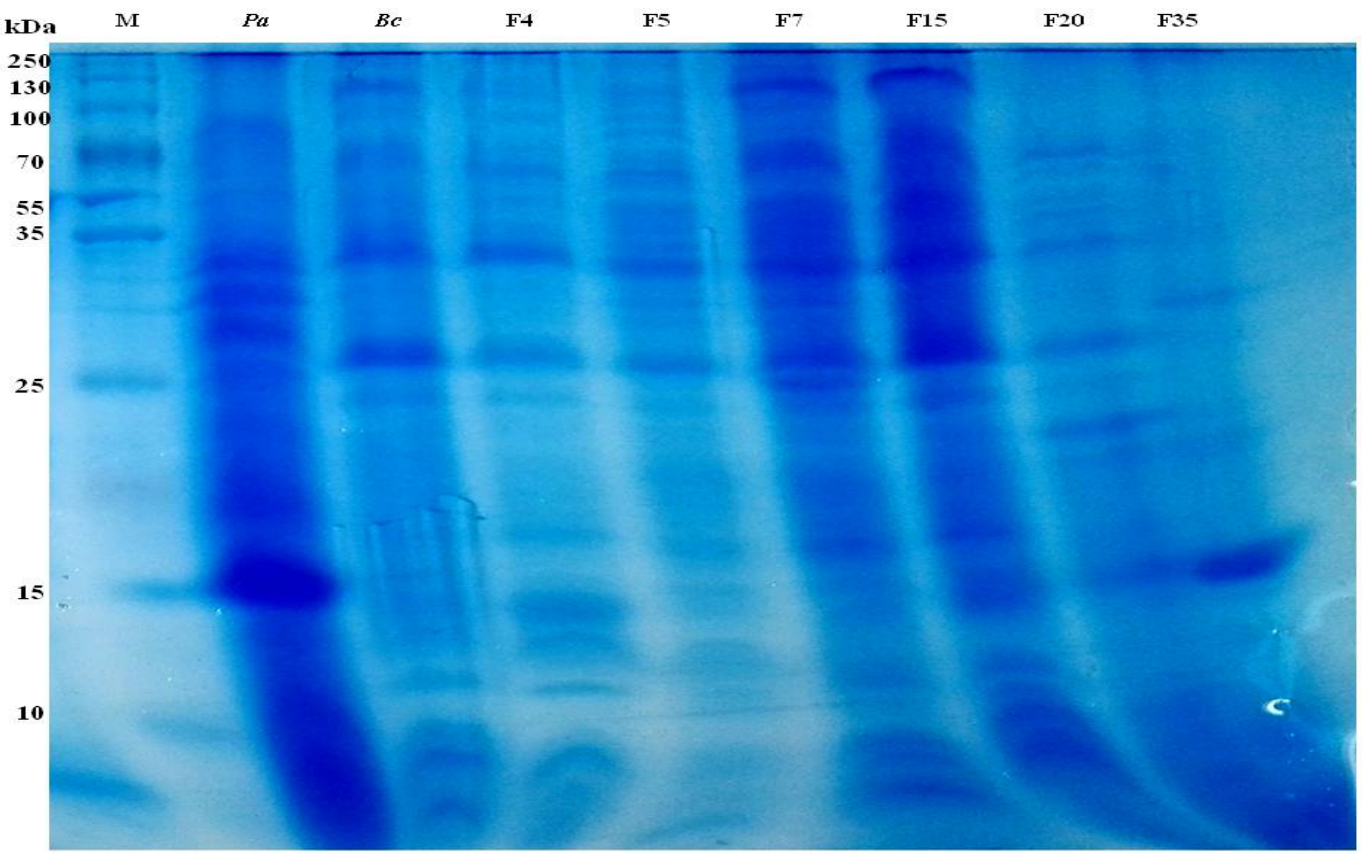

Figure 2. SDS-PAGE protein profiles of the two parental strains; P. arugenosa and B. cereus and their fusant (F). M is the protein marker (Biomatik Corp, (Wilmington, USA) with nine molecular weight bands (kDa).

Table 2. SDS-PAGE analysis of total proteins of the two parental strains P. aeruginosa and B. cereus and six of their fusants.

\begin{tabular}{|c|c|c|c|c|c|c|c|c|c|}
\hline \multirow[t]{2}{*}{ Band No. } & \multirow{2}{*}{$\begin{array}{l}\text { MW KDa } \\
\text { MW }\end{array}$} & \multicolumn{2}{|c|}{ Parental strains } & \multicolumn{6}{|c|}{$P a:: B c$ fusants } \\
\hline & & $\mathrm{Pa}$ & $\mathrm{Bc}$ & F4 & F5 & F7 & F15 & F20 & F35 \\
\hline 1 & 179 & + & & + & + & + & + & + & + \\
\hline 2 & 160 & + & & + & + & & + & + & + \\
\hline 3 & 141 & & - & - & - & - & - & - & - \\
\hline 4 & 126 & + & & + & + & + & + & + & + \\
\hline 5 & 116 & + & & & + & + & + & + & + \\
\hline 6 & 109 & & - & - & - & - & - & - & • \\
\hline 7 & 100 & & - & - & - & - & - & - & - \\
\hline 8 & 92 & + & & & + & + & + & + & + \\
\hline 9 & 83 & + & & + & + & + & + & + & + \\
\hline 10 & 76 & + & & & & + & + & + & + \\
\hline 11 & 67 & & - & - & - & - & - & - & - \\
\hline 12 & 57 & & - & & - & - & - & - & - \\
\hline 13 & 48 & & - & - & & - & - & • & • \\
\hline 14 & 39 & + & & + & + & + & + & + & + \\
\hline 15 & 32 & + & & & + & + & + & + & + \\
\hline 16 & 28 & & - & - & - & - & - & - & - \\
\hline 17 & 24 & & - & - & & - & - & - & - \\
\hline 18 & 19 & & - & - & & - & - & - & - \\
\hline 19 & 15 & & - & - & - & - & - & - & - \\
\hline 20 & 13 & & - & - & - & - & - & - & - \\
\hline 21 & 11 & + & & + & & + & + & + & + \\
\hline 22 & 8 & & - & - & - & - & - & - & - \\
\hline 23 & 7 & + & & + & + & + & + & + & + \\
\hline \multicolumn{2}{|c|}{ Total no. of protein bands } & 11 & 12 & 18 & 18 & 22 & 23 & 23 & 23 \\
\hline \multicolumn{2}{|c|}{$\begin{array}{l}\text { Numbers of } P a \text { bands } \\
\text { expressed in fusants }\end{array}$} & & & 7 & 9 & 10 & 11 & 11 & 11 \\
\hline \multicolumn{2}{|c|}{ Pa bands (\%) } & & & 38.8 & 50 & 45.5 & 47.8 & 47.8 & 47.8 \\
\hline \multicolumn{2}{|c|}{$\begin{array}{l}\text { Numbers of } B c \text { bands } \\
\text { expressed in fusants }\end{array}$} & & & 11 & 9 & 12 & 12 & 12 & 12 \\
\hline \multicolumn{2}{|c|}{ Bc bands(\%) } & & & 61.2 & 50 & 54.5 & 52,2 & 52.2 & 52.2 \\
\hline
\end{tabular}

$(+)$ Refers to presence of protein band of $P a$. $(\bullet)$ Refers to presence of protein band of $B C$

The highest number of $P$. aeruginosa bands (11 bands) was displayed in 3 fusants, while the lowest number (7 bands) was shown by $\mathrm{F} 4$. The total $P$. aeruginosa expressed bands in the rest of the fusants were classified in ascending order as follows: 9 bands in F5, 10 bands in F7, 11 bands in F15, F20 and F35 fusants. On the other hand, variable number of protein bands of $B$. cereus was shown in the fusants. The highest number of $B$. cereus (12 bands) was displayed in 4 fusants, while the lowest number (9 bands) was revealed by F5 fusant. The 6 fusants were characterized based on the absence and presence of the 11 $P$. aeruginosa protein bands. A total of $11 P$. aeruginosa protein bands with different molecular weights were expressed in all the 6 fusants. The presence of the 
remaining 11 bands was distributed in descending order as follows: five bands with molecular weights of 179, 126, 83 , 39 and7 $\mathrm{kDa}$, and five bands were molecular weights $160,116,92,32$ and $11 \mathrm{kDa}$, and one band with molecular weights $76 \mathrm{kDa}$ existed in four fusants, respectively.

The 6 fusants were characterized based on the absence or presence of the expression of the $12 \mathrm{~B}$. cereus protein bands. A total of 8 protein bands with different molecular weights were found in all fusants. The presence of the remaining 8 bands was distributed in descending order among the 6 fusants as follows: each of the eight bands with molecular weights of 141,109,100,67,28,15,13 and $8 \mathrm{kDa}$ was displayed in 6 fusants, while 4 bands with molecular weights of 57, 48, 24 and 19kDa were detected in 5 fusants.

\subsection{Bioassay tests}

3.5.1. The nematicidal potential of $P$. aeruginosa and $B$. cereus parental strains and their fusants against $M$. incognita $\mathrm{J}_{2}$ under laboratory conditions

As illustrated in (Table 3), the bacterial strains under investigation had a lethal effect on $M$. incognita $\mathrm{J}_{2}$ as detected by the percentage mortality when compared to control. The reduction in the movement was irreversible, and the mortality of the juveniles was confirmed when they were transferred to distilled water for 24 hrs. Nematode mortality was positively correlated with suspension concentration and times of exposure. Fusants were more effective than their parent singly or combined. The fusant F35 had shown a strong nematicidal activity against $M$. incognita $\mathrm{J}_{2}$. The recorded percentages mortality as compared to control were $97.7 \%, 90.9 \%$ and $86.3 \%$ for $\mathrm{S}, \mathrm{S} / 2$ and $\mathrm{S} / 4$ concentration respectively, after $72 \mathrm{hrs}$ of exposure (Table 3).

Table 3. The nematicidal potential of $P$. aeruginosa and B. cereus and their fusants on mortality of $M$. incognita juveniles under laboratory conditions.

\begin{tabular}{|c|c|c|c|c|c|c|c|c|c|}
\hline \multirow[t]{3}{*}{ Bacterial strains } & \multicolumn{9}{|c|}{ Percentage mortality at different exposure periods } \\
\hline & \multicolumn{2}{|l|}{$\mathrm{S}$} & \multicolumn{2}{|l|}{$\mathrm{S} / 2$} & \multicolumn{5}{|l|}{$\mathrm{S} / 4$} \\
\hline & 24hrs & 48hrs & 72hrs & 24hrs & 48hrs & $72 \mathrm{hrs}$ & 24hrs & 48hrs & $72 \mathrm{hrs}$ \\
\hline $\mathrm{Pa}$ & 7c & $28.4 \mathrm{~d}$ & $52.2 d$ & $2 \mathrm{e}$ & 25.2c & $35.2 \mathrm{e}$ & $0 \mathrm{c}$ & $10.5 c$ & 14.7e \\
\hline$B c$ & 10c & $46.3 c$ & $65.9 c$ & $5 d$ & $10.5 d$ & $43.1 \mathrm{~d}$ & 1c & $5.2 \mathrm{~cd}$ & $20.4 d$ \\
\hline $\mathrm{Pa}+\mathrm{Bc}$ & $8 c$ & $44.2 \mathrm{c}$ & 48.8d & $2 \mathrm{e}$ & $5.2 \mathrm{e}$ & $28.4 \mathrm{f}$ & 0c & $4.2 \mathrm{~d}$ & 17.1de \\
\hline F 7 & $29 b$ & $48.4 \mathrm{c}$ & $80.6 b$ & $18 \mathrm{c}$ & $36.8 b$ & $62.5 c$ & $10 \mathrm{~b}$ & $25.2 b$ & $48.8 c$ \\
\hline F 20 & $40 a$ & $70.5 a$ & $96.5 a$ & $27 a$ & $56.8 \mathrm{a}$ & $79.5 b$ & $20 a$ & $31.5 a$ & $71.5 b$ \\
\hline F 35 & $30 \mathrm{~b}$ & $55.7 b$ & $97.7 \mathrm{a}$ & $22 b$ & $37.8 b$ & $90.9 a$ & $10 \mathrm{~b}$ & $25.2 b$ & 86.3a \\
\hline Control & --- & --- & --- & ----- & ----- & ----- & ----- & ----- & ---- \\
\hline
\end{tabular}

$\mathrm{Pa}=$ Pseudomonas aeruginosa $\mathrm{Bc}=$ Bacillus cereus $\mathrm{F}=$ fusant $\mathrm{S}=$ Standard concentration Averages followed by same letter(s) are not significantly $(\mathrm{P} \leq 0.05)$ different according to Duncan'sMultiple Range Test

3.5.2. Evaluation of the inhibitory effects of $P$. aeruginosa and $B$. cereus and three fusants on germination of $P$. oleracea and E. crus-galli weed seeds under laboratory conditions

All bacterial suspensions completely inhibited seeds germination of $P$. oleracea as compared to control. $P$. oleracea seeds were swollen in size but did not germinate in a response to all bacterial suspensions (parents and fusants). However, no radicle growth was observed in plates, while E. crus-galli seeds were less influenced than $P$. oleracea seeds. The seeds germinated with small radicle as compared to control. It is worthy to mention that both parents and fusants retard E. crus-galli germination. Moreover, fusants suspensions inhibited the weed germination more than parents suspension.

\section{Discussion}

Protoplast fusion of two parental $\mathrm{Pa}$ and $\mathrm{BC}$ strains was expressed in the 6 selected fusants. SDS-PAGE proteins indicated that some parental protein bands expressed in all fusant strains this study agree with (Khan et al., 1998), who studied the whole cell protein profiles of 42 strains of $P$. aeruginosa, isolated from clinical samples, using the SDS-PAGE method and reported the presence of protein bands, ranging from $340 \mathrm{kDa}$ to $14.3 \mathrm{kDa}$. On the basis of Dice Index of similarity, the strains could be grouped into 20 types. Protoplast fusion has been glorified as the method adequate for a new type and good reproducibility.
The present study demonstrated that biocontrol of $M$. incognita $\mathrm{J}_{2}$ could be effectively achieved using $P$. aeruginosa, B. cereus strains and their fusants. These rhizobacteria appear to suppress root knot nematode via different mechanisms. Oka et al., (1993) reported that ammonia was exited during protein degradation by $B$. cereus improving its nematicidal activity. Xioa et al., (2018) mentioned that the extracellular metabolites like protease, chitinase, and siderophore in $B$. cereus cell free supernatant significantly increase the mortality of $M$. incognita $\mathrm{J}_{2}$ and decrease egg hatching. Chen et al., (2015) mentioned that $P$. aeruginosa can kill nematodes via the production of hydrolytic enzymes, like protease and diffusible toxins like cyanongen, phenazines, and pycoyanin which degrade nematode cuticle and inhibit metabolic pathways. In addition, $P$. aeruginosa has the ability to produce hydrogen cyanide which is responsible for killing nematode (Patil, 2014).

Moreover, the present study indicated that rhizobacterial strains remarkably reduced the germination of $P$. oleracea and E. crus-galli seeds. These are in accordance with the previous studies of (Sardar et al., 2020) who reported that bacteria inhabiting plant rhizospheres could be applied as a biocontrol agent to control weeds associated with rice plants. Also, (Carvalho et al., 2007) found that B. cereus produced at least two phytotoxins which acted a vital role in the production of sodium vanillate and 2-aminobenzoic acid which inhibit lettuce seedling. (Patil, 2014) confirmed the ability of $P$. 
aeruginosa to produce the toxic secondary metabolite hydrogen cyanide inhibiting the enzymes involved in plant respiration, carbohydrate metabolism, $\mathrm{CO}_{2}$ and nitrate assimilation. Lakshmi et al., (2015) mentioned that seed bacterization with $P$. aeruginosa caused reduction in shoot and root length of $P$. oleracea and $A$. spinosus weed seedlings.

Our results illustrate that fusant products were more efficient in killing $M$. incognita $\mathrm{J}_{2}$ and inhibiting germination of seeds weed than their parents. Fusants produced more toxins, antibiotics, and lytic enzymes than the parents, according to (Zaied et al., 2009), who discovered that fusion between Serratia spp. and Pseudomonas spp. produced more chitinases and bacteriocin than the parents, resulting in high mortality levels in nematodes when compared to the parental strains.. Elkylany, (2017) mentioned that fusants from Anoxybacillus flavithermus and $B$. pumilus were more effective in killing $M$. javanica $\mathrm{J}_{2}$ than their parent, and Abdel Salam et al., (2018) discovered that a higher level of chitinase production in the fusants between $B$. amyloliquefaciens subsp. plantarum SA5 and Lysinibacillus sphaericus Amira than the parents resulted in higher nematode mortality..

\section{Conclusion}

We are focusing here on genomics and genetic engineering techniques as helpful tools for developing more powerful biocontrol agents. The efficacy of nematode and weed seeds suppression by tested materials depends on the toxic compound released from these organisms. The obtained fusants from the two local bacterial $P$. aeruginosa and $B$. cereus showed high efficacy against $M$. incognita $\mathrm{J}_{2}$ and $E$. crus-galli and $P$. oleracea seeds germination because they produced more toxins, antibiotic, lytic enzymes than the parent strains. These new strains show great potential to be formulated as an effective biopesticide.

\section{Acknowledgements}

This work was funded by a grant code number 11090408 of In-House project from the National Research Centre, Giza, Egypt.

\section{References}

Abdel-Salam MS, Ameen HH, Soliman GM, Elkelany US and Asar MA. 2018. Improving the nematicidal potential of Bacillus amyloliquefaciens and Lysinibacillus sphaericus against the rootknot nematode Meloidogyne incognita using protoplast fusion technique. Egypt J of Biol Pest Co., 28: 211-216.

Adeux G, Vieren E, Carlesi S, Bàrberi P, Munier-Jolain N, Cordeau S. 2019. Mitigating crop yield losses through weed diversity. Nat sustain., 2: 1018-1026.

Almaghrabi OA, Massoud SI and Abdlmoneim TS. 2013. Influence of inoculation with plant growth promoting rhizobacteria (PGPR) on tomato plant growth and nematode reproduction under greenhouse conditions. Saudi J of Biol Sci., 20: $57-61$.

Byron M, Treadwell D and Dittmar P. 2019. Weeds as reservoirs of plant pathogens affecting economically important crops. IFAS Extension Univ of Florida, HS1335:1-7.
Carvalho DC, Oliveira DF, Correa RS. 2007. Rhizobacteria able to produce phytotoxic metabolites. Braz. Microbiol., 38: 759-765.

Chen L, Jiang H, Cheng Q, Chen J, Wu G, Kumar A, Sun M and Liu Z. 2015. Enhanced nematicidal potential of the chitinase pachi from Pseudomonas aeruginosa in association with Cry21Aa. Scientific Rep., 5:14395 https://doi: 10.1038/srep14395.

Davis RW, Botstein D and Rotho JR. 1980. Transfection of DNA. in Bacterial Genetics: A Manual for Genetic Engineering Advanced Bacterial Genetic. CSHL New York, 67:134-137.

El-Kawokgy TM, Hussein HA, Aly NA and Mohamed SAH. 2015. Highly toxic and broad-spectrum insecticidal local Bacillus strains engineered using protoplast fusion. Can. Journal of Microbiol., 61: 38-47.

Elkelany US. 2017. Controlling of root-knot nematodes in eggplant using genetically improved bacteria. PhD Thesis, Fac Agric, Ain Shams Univ., 197pp.

Hussain S, Khaliq BAA, Matloob A, Areeb A, Ashraf U, Hafeez A, Imran M. 2017. Crop growth yield losses in wheat due to little seed Canary grass infestation differ with weed densities and changes in environment, Planta Daninha, 35 (e017162328): 1-15.

Hussey RS and Barker KR. 1973. A comparison of methodsof collecting inocula of Meloidogyne spp. including a new technique. Plant Dis Rep., 57: 1025-1028.

Jabran K, Mahajan G, Sardana V, Chauhan BS. 2015. Allelopathy for weed control in agricultural systems. Crop Prot., 72: 57-65. Doi: https://doi.org/10.1016/j.cropro.2015.03.004

Khan FG, Ashok R, Khan IA, Kalia A. 1998. Study of Pseudomonas aeruginosa causing ventilator associated pneumonia. Ind J Med Res., 107: 68- 74.

Laemmli UK. 1970. Cleavage of structural proteins during assembly of the head of bacteriophage T4. Nat., 227:680-685.

Lakshmi VS, Kumari S, Singh A and Prabha C. 2015. Isolation and characterization of deleterious Pseudomonas aeruginosa KC1 from rhizospheric soils and its interaction with weed seedlings. $J$ of King Saud Univ Sci., 27(2): 113-119.

Lee Yand Kim K. 2016. Antagonistic potential of Bacillus pumilus L1 against root-knot nematode, Meloidogyne arenaria. $J$ Phytopathol., 164:29-39.

Mohamed SAH, Ibrahim SA, Soliman KHA, Abd-El-Aal SKH, Moawad SS, and Attallah AG. 2016. Genetic improvement of some microorganisms that naturally colonize of tomato plants to increase the effect of bio-control on Tuta absoluta. Res J Pharm Biol Chem Sci., 7: 1502- 1518.

National Committee for Clinical Laboratory Standards (NCCLS). 1999. Performance standards for antimicrobial susceptibility testing; ninth informational supplement, Document M100- S9. Wayne Pennsylvania 9, 1.

Oka Y, Chet I, Spiegel Y. 1993. Control of the rootknot nematode Meloidogyne javanica by Bacillus cereus. Biocontrol Sci Technol., 3:115-126.

Patil VS. 2014. Isolation, characterization and identification of rhizospheric bacteria with the potentialfor biological control of sida acuta. J of Environ Res and Develop., 8(3): 411-417.

Sardar MF, Siddique S, Abbas T, Aziz MZ, Naveed M, Khan S. 2020. Biological weeds control in rice (oryza sativa) using beneficial plant growth promoting rhizobacteria. Int J Agric Biol., 23(3):522-528.

Sayed MHE, Aziz ZKA and Abouzaid AM. 2014. Efficacy of extracellular metabolite produced by Streptomyces levis strain LX-65 as a potential herbicidal agent. J Am Sci., 10: 169-80.

Schisler DA, Slininger PJ, Bothast RJ. 1997. Effects of antagonist cell concentration and two-strain mixtures on biological control of Fusarium dry rot of potatoes. J Phytopathol., 87: 177-183. 
Siddiqui IA, Shaukat SS, Khan GH and Ali NI. 2003. Suppression of Meloidogyne javanica by Pseudomonas aeruginosa IE-6S+ in tomato: the influence of $\mathrm{NaCl}$, oxygen and iron levels. Soil Biol Biochem.35:1625-1634.https://doi: 10.1016/j.soilbio.2003.08.007.

Singh S, Singh B, and Singh A P. 2015. Nematodes: a threat to sustainability of agriculture. Procedia Environ Sci., 29: 215-216. doi: 10.1016/j.proenv.2015.

Soliman GM, Ameen HH, Abdel-Aziz SHM and El-sayed GM. 2019. In vitro evaluation of some isolated bacteria against the plant parasite nematode Meloidogyne incognita. Bull Natl Res Cent., 43:171. https://doi.org/10.1186/s42269-019-0200-0.

Soliman GM, Ameen HH, Abd-El-Khair H, El-Nagdi WMA and E-lsayed GM. 2018. Isolation, identification, and improving nematotoxicity of rhizobacterial strains against Meloidogyne incognita. Egypt Pharmaceut J., 17:27-31.
Soliman GM, Mohamed SAH, Haggag LF and El-Hady ES. 2020. Efficiency of biological control of root-knot nematodes in infected grapevines seedling by genetic improved bacteria. Plant arch., 20(1): 951-961.

Taylor AL and Sasser JN. 1978. Biology, identification and control of root-knot nematodes (Meloidogyne species) Raleigh, NC, North Carolina State Univ. Graph.

Xiao L, Wan JW, Yao JH, Feng H and Wei LH. 2018. Effects of Bacillus cereus strain Jdm1 on Meloidogyne incognita and the bacterial community in tomato rhizosphere soil. Biotech., 8: 319327.https://doi.org/10.1007/s13205-018-1348-2.

Zaied KA, Kawther S, Kash S, Ibrahim A and Tawfik TM. 2009. Improving Nematocidial activity of bacteria via protoplast Fusion. Australian J of Basic and Appl Sci., 3(2): 1412- 1427. 